\title{
Family vs career aspiration among female agricultural graduates
}

\author{
SERENE SHEKHAR, SARITA SANWAL AND M.K. CHAUDHARY
}

Received: 11.07.2016; Revised: 24.10.2016; Accepted: 05.11.2016

See end of the paper for authors' affiliations

SERENE SHEKHAR

Department of Extension and Communication Management,

Sardarkrushinagar Dantiwada Agricultural

University, S.K. NAGAR (GUJARAT) INDIA (Email : shekhar.sdau@gmail.com

\begin{abstract}
Industrialization and socio-educational advancement has created opportunities for women to work while raising a family and thereby contributing to Indian economy. The study was undertaken under AGRESCO project, in seven colleges of Sardarkrushinagar Dantiwada Agricultural University of Gujarat state; to seek answer that whether the female students prefer career or/and family in modern society. A pre-structured interview scheduled and a standardized tool was used to measure independent variables and dependent variable (career and family values scale), respectively. Frequency, percentage, range, correlation coefficient and CRD were used to tabulate the data. The findings revealed that 57.33 per cent of the agricultural university graduates (female) had medium career value and majority $(74.67 \%$ ) of the respondents had higher family values. Only 21.33 per cent of respondents were willing to seek job or any entrepreneurial venture and that too after completion of post graduation. Among seven colleges, College of Dairy Science and Food Technology ranked first in career value. No significant difference for the family value among girl students of various colleges was obtained. Career value and family value of the respondents was not correlated. Programme of study and father occupation and education showed positive and significant association with career values of the respondents.
\end{abstract}

KEY WORDS: Female student, Preference, Career, Family value

- HOW TO CITE THIS PAPER : Shekhar, Serene, Sanwal, Sarita and Chaudhary, M.K. (2016). Family vs career aspiration among female agricultural graduates. Asian J. Home Sci., 11 (2) : 394-399, DOI: 10.15740/HAS/AJHS/11.2/394-399. 